\title{
EFEKTIVITAS PENDEKATAN MATEMATIKA RELISTIK UNTUK MENINGKATKAN AKTIVITAS BELAJAR DAN KEMAMPUAN REPRESENTASI MATEMATIS SISWA
}

\author{
Reni Puspita Ningsih \\ ${ }^{1}$ Jurusan Pendidikan Matematika, FKIP, Universitas Lampung, \\ Jl. Prof. Dr. Soemantri Brojonegoro \\ e-mail: renipuspita67@gmail.com
}

\begin{abstract}
This study aims to determine the effectiveness of a realistic mathematical approach to improve learning activities and students' mathematical representation abilities. The population in this study were all seventh grade students in one of the public junior high schools in Bandar Lampung in the 2011/2012 academic year which were divided into 9 classes with class divisions consisting of 3 classes with high early ability, 3 classes with moderate early ability, and 3 classes with moderate ability. low start. The students' initial abilities are taken from students' national exam scores at the elementary school level. The class taken in this study is a class that has a high initial ability. Sampling was taken using the Purposive Random Sampling Technique. The samples taken in this study were 2 classes of high early ability from 3 classes of high early ability and obtained classes VII C and VII D which consisted of 65 students with 34 male students and 31 female students. Data was collected using observation techniques based on observation sheets and test techniques using test instruments that were arranged based on the indicators to be achieved. As for what can be concluded from this research is the Realistic Mathematics Approach is effectively applied to the mathematics learning of students with high initial ability to improve learning activities and mathematical representation abilities.
\end{abstract}

Keywords: information technology, mathematics, media learning

\begin{abstract}
Abstrak
Penelitian ini bertujuan untuk mengetahui efektivitas pendekatan matematika realistik untuk meningkatkan aktivitas belajarn dan kemampuan representasi matematis siswa. Populasi dalam penelitian ini adalah seluruh siswa kelas VII di salah satu SMP Negeri di Kota Bandar Lampung tahun pelajaran 2011/2012 yang terbagi dalam 9 kelas dengan pembagian kelas yang terdiri dari 3 kelas berkemampuan awal tinggi, 3 kelas berkemampuan awal sedang, dan 3 kelas berkemampuan awal rendah. Kemampuan awal siswa diambil dari nilai ujian nasional siswa pada jenjang sekolah dasar. Kelas yang diambil dalam penelitian ini adalah kelas yang mempunyai kemampuan awal tinggi. Pengambilan sampel diambil dengan menggunakan Teknik Purposive Random Sampling. Sampel yang diambil dalam penelitian ini adalah 2 kelas berkemampuan awal tinggi dari 3 kelas berkemampuan awal
\end{abstract}




\section{Hipotenusa}

Journal of Research Mathematics Education

VOL. 4 NO. 12021

tinggi dan diperoleh kelas VII C dan VII D yang terdiri dari 65 siswa dengan 34 siswa laki- laki dan 31 siswa perempuan. Pengumpulan data dilakukan dengan teknik observasi yang dilakukan berdasarkan lembar observasi dan teknik tes menggunakan instrumen tes yang disusun berdasarkan indikator yang ingin dicapai. Adapun yang dapat disimpulkan dari penelitian ini adalah Pendekatan Matematika Realistik efektif diterapkan pada pembelajaran matematika siswa berkemampuan awal tinggi untuk meningkatkan aktivitas belajar dan kemampuan representasi matematis.

Kata kunci: matematika, media pembelajaran, teknologi informasi

\section{PENDAHULUAN}

Pembelajaran yang efektif merupakan pembelajaran yang memberikan kesempatan seluas-luasnya kepada siswa untuk dapat belajar mandiri dengan mudah, menyenangkan dan mencapai tujuan pembelajaran sesuai dengan yang diharapkan [1], [2]. Proses pembelajaran yang interaktif, inspiratif, menyenangkan, menantang, dan memotivasi peserta didik untuk berpartisipasi aktif, serta memberikan ruang yang cukup bagi prakarsa, kreativitas, dan kemandirian sesuai dengan bakat, minat, dan perkembangan fisik serta psikologis peserta didik sangat diperlukan untuk mencapai tujuan pembelajaran [3].

Satu diantara beberapa cara terbaik untuk membantu siswa dalam memahami matematika adalah dengan mendorong siswa untuk menemukan atau membuat representasi sebagai alat berpikir dalam mengkomunikasikan gagasan matematika [4]. Mudzzakir menyatakan bahwa representasi merupakan salah satu kunci keterampilan komunikasi matematis [5]. Untuk mencapainya diperlukan sajian masalah-masalah yang bersifat konkrit untuk membantu memahami ide-ide matematika yang bersifat abstrak tersebut, sehingga dalam proses pembelajarannya diperlukan kemampuan representasi yang baik.

Subandar mengemukakan bahwa kemampuan representasi matematis dapat ditingkatkan melalui proses penemuan kembali dengan konsep matematisasi horizontal dan vertikal [4]. Pada konsep 
matematisasi horizontal siswa memulai dari soal-soal kontekstual, mencoba menguraikan dengan bahasa dan simbol yang dibuat sendiri, kemudian menyelesaikan soal tersebut [5]. Setiap orang dapat menggunakan cara mereka sendiri yang mungkin berbeda dengan orang lain. Dengan demikian siswa dapat mengidentifikasi, merumuskan, dan memvisualisasikan masalah dalam cara-cara berbeda, dan mentransformasikan masalah dunia real ke masalah matematika. Sedangkan konsep matematisasi vertikal berupa representasi hubungan-hubungan dalam rumus, membuktikan aturan, membuat generalisasi, penyesuaian model matematika, dan lain-lain [6].

Salah satu faktor yang mempengaruhi kemampuan representasi matematis siswa adalah kemampuan awal siswa, yaitu kemampuan yang telah melekat pada diri seseorang yang terkait dengan hal baru yang akan dipelajari. Kemampuan awal ini menggambarkan kesiapan siswa dalam menerima pelajaran yang akan dipelajari selanjutnya. Kemampuan awal sangat penting pada pembelajaran matematika karena pembelajaran matematika merupakan pembelajaran yang struktural dan berjenjang sehingga setiap materi yang akan dipelajari selalu berkaitan dengan materi yang sebelumnya.

Berdasarkan hasil wawancara dengan guru matematika yang mengajar di kelas VII di salah satu SMP Negeri di Kota Bandar Lampung, kemampuan representasi matematis siswa pada kelas yang mempunyai kemampuan awal tinggi tidak jauh berbeda dengan kelas yang mempunyai kemampuan awal sedang ataupun rendah. Hal ini disebabkan karena pembelajaran yang dilakukan masih menggunakan pembelajaran konvensional. Siswa hanya mendengar, mencatat penjelasan yang diberikan oleh guru, lalu siswa diberi beberapa contoh soal dan pekerjaan rumah. Akibatnya apabila siswa diberikan masalah matematis yang berbeda dengan latihan atau contoh soal siswa tidak mampu merepresentasikan masalah matematis tersebut kedalam persamaan atau ekspresi matematis dan kata-kata atau teks tertulis. Begitu juga apabila guru meminta siswa untuk mengulas kembali materi yang telah dipelajari sebagian besar siswa lebih 
memilih untuk diam. Dengan demikian siswa cenderung lebih pasif dan menerima apa yang telah diberikan oleh guru tanpa ada timbal balik antara guru dengan siswa dan antara siswa dengan siswa.

Selain pembelajaran, aktivitas belajar siswa juga sangat mempengaruhi dalam pembentukan kemampuan representasi matematis siswa. Sardiman mengemukakan bahwa dalam belajar diperlukan aktivitas, sebab pada prinsipnya belajar adalah berbuat, berbuat untuk mengubah tingkah laku [7]. Aktivitas siswa merupakan segala kegiatan siswa yang dilakukan pada saat proses pembelajaran. Lebih luas, aktivitas belajar menjadi salah satu faktor yang berpengaruh terhadap pembelajaran sehingga siswa dapat memahami pembelajaran dengan baik.

Salah satu pembelajaran yang cocok untuk meningkatkan aktivitas dan kemampuan representasi matematis siswa adalah dengan menggunakan Pendekatan Matematika Realistik (PMR). PMR merupakan salah satu pendekatan yang berorientasi pada matematisasi pengalaman sehari-hari (mathematize of everyday experience). De Lange, Streeffland, dan Gravemeijer mengemukakan bahwa karakteristis dari PMR adalah menggunakan maalah kontekstual, menggunakan model atau jembatan dengan instrumen vertikal, melibatkan kontribusi siswa, menciptakan situasi interaktif dan menggunakan keterkaitan [8]. Pembelajaran dengan PMR menekankan pada konstruksi dari benda-benda konkrit sebagai titik awal bagi siswa dalam memahami konsep representasi matematis yang ada. Penerapan pendekatan pembelajaran yang mengaitkan materi matematika dalam kehidupan nyata akan mempermudah siswa dalam memahami materi yang dipelajari. 


\section{METODE PENELITIAN}

Populasi dalam penelitian ini adalah seluruh siswa kelas VII di salah satu SMP Negeri di Kota Bandar Lampung tahun pelajaran 2011/2012 yang terbagi dalam 9 kelas dengan pembagian kelas yang terdiri dari 3 kelas berkemampuan awal tinggi, 3 kelas berkemampuan awal sedang, dan 3 kelas berkemampuan awal rendah. Kemampuan awal siswa diambil dari nilai ujian nasional siswa pada jenjang sekolah dasar. Hal ini dilakukan karena pada materi yang akan diambil dalam penelitian yaitu materi aritmatika sosial sangat berkaitan dengan materi pada jenjang sekolah dasar. Kelas yang diambil dalam penelitian ini adalah kelas yang mempunyai kemampuan awal tinggi. Pengambilan sampel diambil dengan menggunakan Teknik Purposive Random Sampling. Sampel yang diambil dalam penelitian ini adalah 2 kelas berkemampuan awal tinggi dari 3 kelas berkemampuan awal tinggi dan diperoleh kelas VII C dan VII D yang terdiri dari 65 siswa dengan 34 siswa laki- laki dan 31 siswa perempuan. Pengumpulan data dilakukan dengan teknik observasi yang dilakukan berdasarkan lembar observasi dan teknik tes menggunakan instrumen tes yang disusun berdasarkan indikator yang ingin dicapai.

\section{HASIL DAN PEMBAHASAN}

Berdasarkan analisis data observasi diperoleh hasil yaitu pada pembelajaran Kovensional tidak semua indikator aktivitas siswa dilakukan dalam proses pembelajaran. Indikator aktivitas siswa yang dilakukan dalam proses pembelajaran meliputi: memperhatikan penjelasan/demonstrasi guru sebesar 85,64\%, menjawab pertanyaan atau bertanya kepada guru sebesar $34,36 \%$, dan mengerjakan latihan individu sebesar 86,15\%. Aktivitas belajar yang paling banyak dilakukan adalah memperhatikan penjelasan/demonstrasi guru dan mengerjakan latihan individu. Sedangkan aktivitas yang paling sedikit atau tidak dilakukan adalah diskusi antar sesama siswa, 
mempresentasikan/ menanggapi presentasi hasil diskusi, dan memperhatikan presentasi hasil diskusi. Dalam setiap pertemuan, aktivitas siswa cenderung semakin meningkat. Hal ini terlihat dari persentase aktivitas siswa yang setiap pertemuan cenderung meningkat, yaitu: pada pertemuan pertama siswa yang aktif $63,64 \%$, pada pertemuan kedua dan ketiga siswa yang aktif sebesar $72,73 \%$ dan 78,79\%, pada pertemuan selanjutnya siswa yang aktif sedikit mengalami penurunan yaitu pertemuan keempat siswa yang aktif $78,13 \%$, pada pertemuan berikutnya siswa yang aktif $81,25 \%$, bahkan pada pertemuan terakhir yaitu pertemuan keenam siswa yang aktif mencapai 84,38\%. Sehingga, dari keseluruhan data diperoleh rata-rata siswa aktif sebesar $76,49 \%$, sedangkan rata-rata siswa yang tidak aktif sebesar $23,51 \%$

Pada pembelajaran dengan menggunakan pendekatan matematika realistik (PMR) semua indikator aktivitas belajar siswa dilakukan pada proses pembelajaran. Indikator aktivitas belajar siswa meliputi: memperhatikan penjelasan/demonstrasi guru sebesar 91,28\%, menjawab pertanyaan atau bertanya kepada guru sebesar 43,59\%, diskusi antar sesama siswa 92,31\%, mempresentasikan/ menanggapi presentasi hasil diskusi 24,10\%, memperhatikan presentasi hasil diskusi 90,77\%, dan mengerjakan latihan individu sebesar 81,03\%. Jumlah aktivitas yang paling banyak dilakukan adalah diskusi antar sesama siswa, sedangkan jumlah aktivitas yang paling sedikit dilakukan adalah mempresentasikan/ menanggapi presentasi hasil diskusi.

Banyaknya siswa yang aktif pada pembelajaran dengan menggunakan PMR dalam setiap pertemuan meningkat. Hal ini juga terlihat dari semakin meningkatnya persentase siswa yang aktif pada setiap pertemuan, yaitu: pada pertemuan pertama siswa yang aktif $59,37 \%$, pada pertemuan kedua dan ketiga siswa yang aktif sama yaitu $62,50 \%$, pada pertemuan selanjutnya yaitu pertemuan keempat siswa yang aktif $84,85 \%$, pada pertemuan berikutnya siswa yang aktif 93,94\%, bahkan pada pertemuan terakhir yaitu pertemuan keenam siswa yang aktif mencapai 100\%. Dari data keseluruhan diperoleh 
rata-rata siswa yang aktif sebesar $77,19 \%$ dan rata-rata siswa yang tidak aktif sebesar 22,81\%.

Dari uraian di atas diperoleh hasil bahwa dalam pembelajaran konvensional tidak semua indikator aktivitas belajar siswa dilakukan dalam proses pembelajaran. Sedangkan pada pembelajaran dengan menggunakan PMR semua indikator aktivitas pembelajaran dilakukan oleh siswa meskipun tidak semua siswa melakukan indikator aktivitas belajar tersebut. Namun dengan demikian, rata-rata siswa yang aktif yang belajar dengan menggunakan pembelajaran Konvensional tidak jauh berbeda dengan rata-rata siswa yang aktif yang belajar dengan menggunakan PMR. Sehingga dapat disimpulkan bahwa aktivitas belajar siswa dengan menggunakan PMR sama baiknya dengan aktivitas belajar siswa dengan pembelajaran Konvensional.

Pembelajaran dengan menggunakan Pendekatan Matematika Realistik diawali dengan memberikan masalah kontekstual sehingga memungkinkan siswa menggunakan pengalaman sebelumnya untuk menyelesaikan masalah yang mereka hadapi saat ini. Pendekatan Matematika realistik tidak hanya mengacu pada realita tetapi juga pada sesuatu yang dapat dibayangkan oleh siswa sehingga hal tersebut dapat digunakan oleh siswa dalam pengembangan konsepkonsep atau gagasan-gagasan matematis.

Berdasarkan analisis data dan pengujian hipotesis diketahui bahwa pembelajaran dengan menggunakan PMR mampu mendorong siswa untuk lebih aktif dalam mengikuti pembelajaran dan mampu membantu siswa dalam memahami masalah yang dihadapi. Hal ini dapat dilihat berdasarkan deskripsi aktivitas siswa, terlihat bahwa pembelajaran dengan menggunakan PMR dapat meningkatkan aktivitas belajar siswa. Siswa tidak hanya mampu menyelesaikan masalahnya sendiri, melainkan siswa mampu bertanggungjawab dalam kelompoknya untuk menyelesaikan masalah yang mereka hadapi. Selain itu, siswa juga mampu membantu siswa lain yang kesulitan dalam memahami masalah pada kelompoknya sehingga siswa yang kesulitan tersebut dapat memahami dan menyelesaikan masalah yang ada. 
Pembelajaran dengan menggunakan PMR juga dapat meningkatkan kepercayaan diri siswa, sehingga siswa mempunyai kepercayaan diri untuk mempresentasikan hasil diskusi kelompoknya. Siswa yang sebelumnya pasif atau hanya menerima apa yang diberikan oleh guru mendapatkan dorongan dari siswa yang lain untuk dapat menyampaikan pendapat mereka tanpa adanya rasa takut. Diakhir pembelajaran, siswa bersama-sama dengan guru menyimpulkan materi pembelajaran sehingga tidak akan terjadi kesimpangsiuran atau perbedaan hasil dari penyelesaian masalah dan materi yang dipelajari.

Pembelajaran dengan menggunakan PMR siswa diberikannya masalah sehingga siswa akan terdorong untuk mempu merepresentasikan masalah tersebut kedalam kata-kata atau simbol matematis. Dengan kemampuan siswa merepresentasikan masalah, maka siswa akan lebih memahami konsep matematika.

Pada pokok bahasan aritmatika sosial ini siswa dituntut untuk memahami konsep materi melalui diskusi kelompok. Setiap kelompok terdiri dari 4 sampai 5 orang siswa yang kemampuan awalnya heterogen untuk setiap kelompok. Dengan diskusi kelompok tersebut, siswa yang kurang mampu pada kelompok tersebut dapat dibantu oleh anggota lain pada kelompok yang sama yang sudah memahami masalah yang dihadapi. Dengan demikian setiap anggota atau siswa lebih cepat memahami konsep yang sedang dipelajari. Setiap kelompok terlibat aktif dalam penyelesaian masalah yang disajikan dalam lembar kerja kelompok. Dalam lembar kerja kelompok tersebut disajikan langkah-langkah dalam penyelesaian masalah yang ada, sehingga dapat membantu siswa dalam merubah masalah dalam representasi simbol atau kata-kata matematis. Siswa yang mampu merubah masalah kedalam kata-kata atau simbol matematis akan lebih cepat memahami konsep materi yang diberikan. Hal ini terlihat dari uji hipotesis 2 yang menyatakan bahwa tes kemampuan representasi maatematis siswa berkemapuan awal tinggi yang belajar dengan menggunakan PMR memiliki kemampuan representasi matematis lebih baik daripada siswa berkemampuan awal tinggi yang belajar dengan menggunakan pembelajaran Konvensional. 
Setelah siswa selesai berdiskusi untuk menyelesaikan masalah dalam LKK, maka setiap kelompok harus mempresentasikan hasil diskusi kelompoknya. Dengan presentasi tersebut, siswa dituntut untuk berani dan aktif menyampaikan pendapat penyelesaian masalah yang sudah mereka tuangkan dalam LKK. Siswa yang tidak mempresentasikan hasil diskusi dituntut untuk memperhatikan dan memberikan tanggapan terhadap siswa lain yangs sedang mempresentasikan hasil diskusinya. Presentasi ditutup dengan diskusi kelas. Diskusi kelas tersebut dimaksudkan untuk menyamakan pemahaman siswa antar kelompok berbeda. Dengan adanya diskusi kelas maka pembelajaran lebih aktif karena terdapat interaksi antas siswa dan antara guru dengan siswa.

Penyajian masalah matematika dengan mengaitkan dunia nyata atau masalah yang sering dihadapi dalam kehidupan sehari-hari dan dengan pemahaman yang sudah didapat sebelumnya akan membantu siswa untuk mampu menentukan konsep materi yang sedang dipelajarinya sendiri. Oleh karena itu, guru harus memiliki kemampuan kreativitas yang tinggi untuk mampu menyajikan konsep matematika kedalam masalah yang mudah dipahami dan dipelajari olehs siswa. Selain itu, guru juga harus mampu mendorong siswa untuk mampu mengeluarkan pendapat yang ada dalam pikiran siswa sehingga siswa mampu menyelesaiakan masalah yang ada dengan menggunakan representasi matematis. Siswa yang mampu merepresentasikan masalah matematis dengan baik maka siswa tersebut sudah memahami konsep dari masalah tersebut.

Dalam pelaksanaannya diskusi kelompok membutuhkan waktu yang lama, oleh sebab itu guru sebagai fasilitatos harus mampu mengelola pembelajaran dengan baik agar pembelajarannya efektif. Salah satunya yaitu dalam presentasi, tidak semua kelompok mempresentasikan hasil diskusinya melainkan hanya perwakilan kelompok saja. Dengan adanya strategi pembelajaran yang baik maka akan membantu tercapainya tujuan pembelajaran.

Seperti yang dijelaskan pada Bab III bahwa untuk penilaian kemampuan representasi matematis siswa dilihat dari 3 aspek, yaitu: 


\section{Hipotenusa}

Journal of Research Mathematics Education VOL. 4 NO. 12021

(1) ketepatan perhitungan, (2) penjelasan, (3) jawaban yang didapat. Berdasarkan dari lampiran 6 terlihat bahwa kemampuan siswa dalam melakukan perhitungan atau dalam ketepatan perhitungan sudah baik, tetapi kemampuan siswa dalam menjelaskan dan jawaban yang didapat masih kurang baik. Hal tersebut terlihat bahwa masih banyak siswa yang hanya mampu menyelesaikan masalah tetapi tidak mampu menjelaskan secara tertulis maksud dari masalah yang dihadapi dan siswa sering lupa menyimpulkan jawaban dari masalah yang sudah mereka selesaikan. Selain itu, hampir sebagian besar siswa tidak mampu menggambarkan masalah ke dalam representasi dengan dunia nyata atau dengan simbol matematika. Hal itu yang menyebabkan skor tes kemampuan representasi matematis siswa rendah.

\section{KESIMPULAN DAN SARAN}

Berdasarkan hasil penelitian dan pembahasan dapat disimpulkan bahwa Pendekatan Matematika Realistik efektif diterapkan pada pembelajaran matematika siswa berkemampuan awal tinggi untuk meningkatkan aktivitas belajar dan kemampuan representasi matematis siswa kelas VII di salah satu SMP Negeri di Kota Bandar Lampung semester ganjil Tahun Pelajaran 2011/2012. Hal ini dapat ditunjukkan dengan :

1. Aktivitas belajar siswa berkemampuan awal tinggi yang belajar dengan menggunakan PMR sama baiknya dengan aktivitas belajar siswa berkemampuan awal tinggi yang belajar dengan menggunakan pembelajaran kovensional.

2. Kemampuan representasi matematis siswa berkemampuan awal tinggi yang belajar dengan menggunakan PMR lebih baik daripada kemampuan representasi matematis siswa berkemampuan awal tinggi yang belajar dengan menggunakan pembelajaran konvensional. 


\section{Hipotenusa}

Berdasarkan kesimpulan yang ada, maka pendekatan matematika realistik dapat diterapkan pada pembelajaran di kelas untuk meningkatkan aktivitas belajar siswa dan kemampuan representasi matematis siswa. Bagi peneliti lain yang ingin melakukan penelitian sejenis, maka dapat melakukan penelitian dengan variabel yang lebih luas agar dapat memperkaya informasi.

\section{DAFTAR PUSTAKA}

[1] Sutikno, M. Sobry.2005. Pembelajaran Efektif.NTP Pres.Mataram.

[2] Hamalik, Oemar. 2004. Proses Belajar Mengajar. Bumi Aksara. Jakarta.

[3] BSNP. 2007. Peraturan Menteri Pendidikan Nasional Republik Indonesia Nomor 41 Tahun 2007 Tentang Standar Proses untuk Satuan Pendidikan Dasar dan Menengah. Depdiknas. Jakarta.

[4] Hutagaol, K. 2007. Pembelajaran Kontekstual Untuk Meningkatkan Kemampuan representasi siswa SMP. Tesis Pada Program Pasca Sarjana UPI Bandung: Tidak dipublikasikan

[5] Mudzzakir, Hera S. 2006. Strategi Pembelajaran "Think-Talk-White” untuk meningkatkan kemampuan representasi matematik Beragam Siswa SMP. Tesis Pada Program Pasca Sarjana UPI Bandung: Tidak dipublikasikan

[6] Hadi, Sutarto. 2005. Pendekatan Matematika Realistik. Tulip. Banjarmasin.

[7] Sardiman, AM. 2004. Interaksi dan Motivasi Belajar Mengajar. Raja Grafindo Persada. Jakarta.

[8] Putri, Ratu Ilma Indra. 2003. Pengevaluasian Perangkat Pembelajaran Statik Menggunakan Pendekatan Pendidikan Matematika Indonesia di SLTPN 17 Palembang. Tesis. Palembang 